\title{
Infection Control
}

\section{Hospital Epidemiology}

Volume 36, No 2

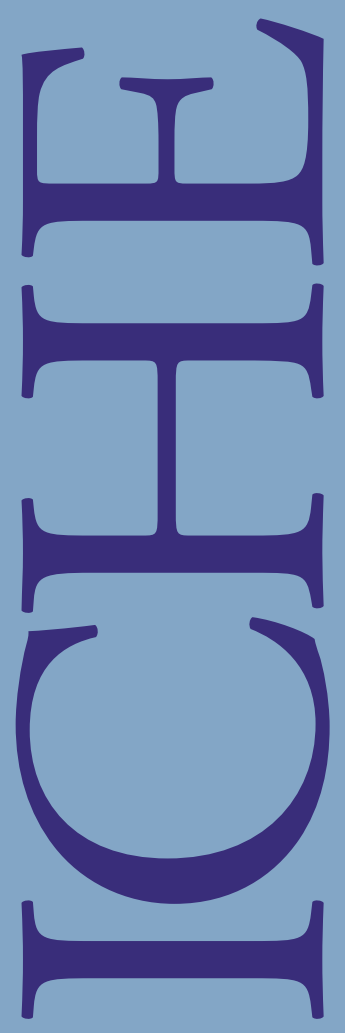

IGNAZ SEMMELWEISS 

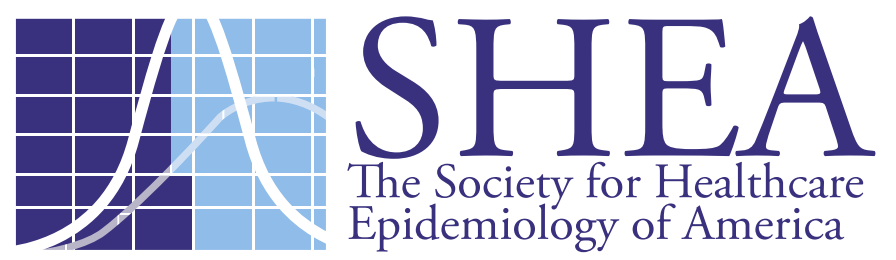

The Society for Healthcare Epidemiology of America

\section{Spring 2015 Conference SCIENCE GUIDING PREVENTION}

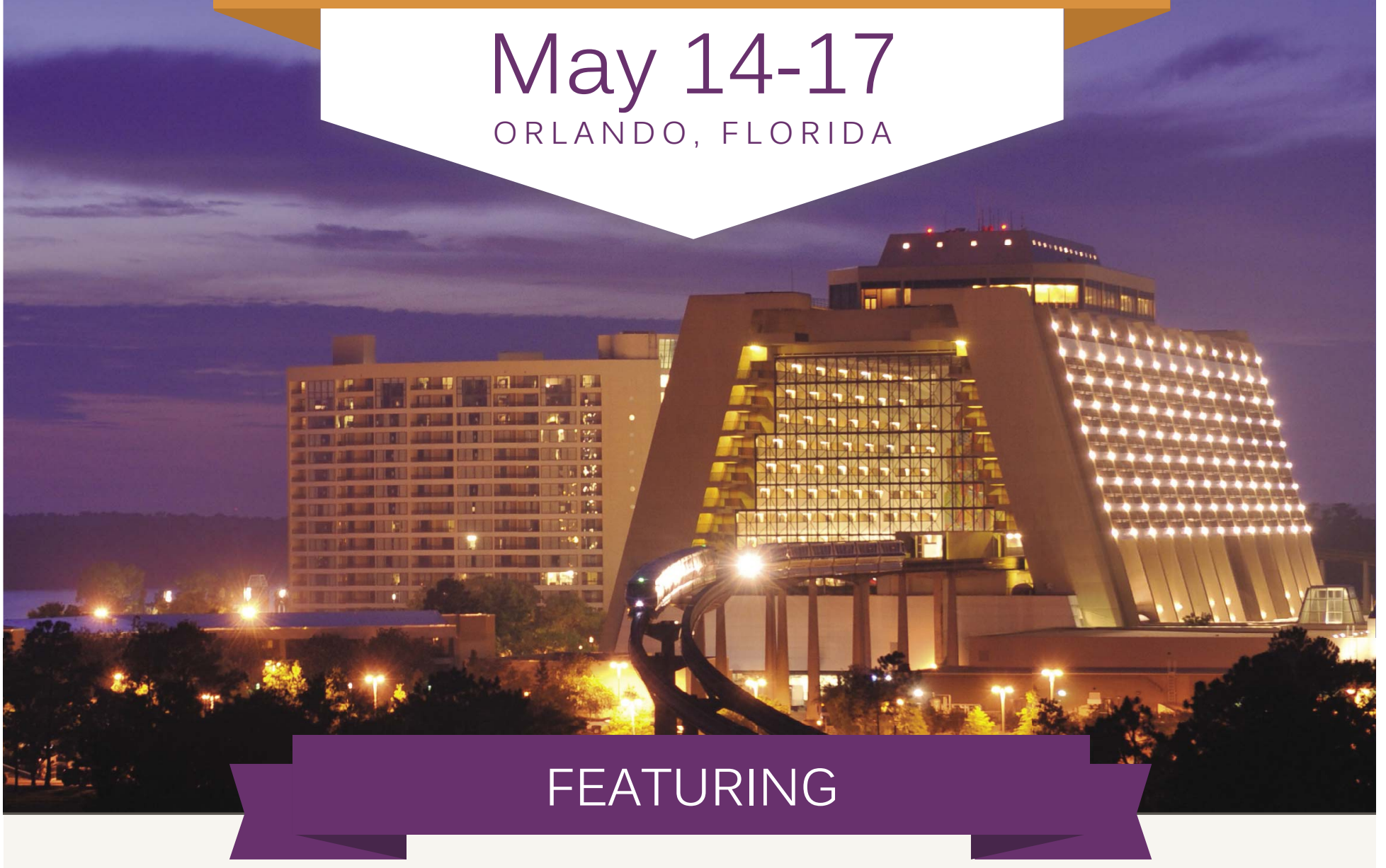

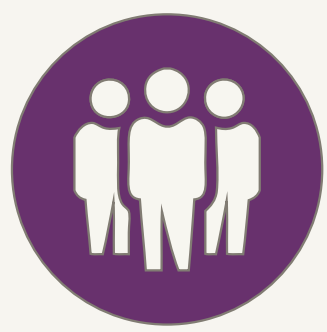

Expanded Networking \& Mentoring Opportunities

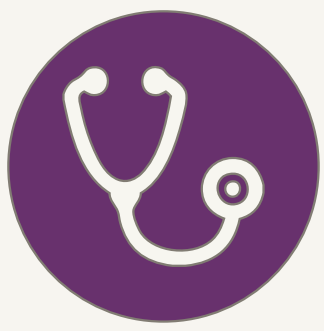

Focused Workshops on

Pediatrics \& Antimicrobial Stewardship

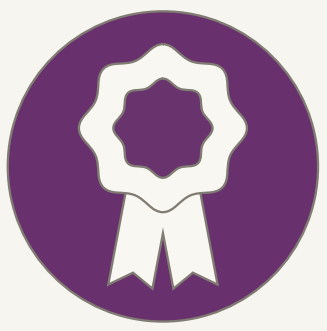

Two SHEA Certificate

Course Tracks 


\section{CONTENTS}

\section{Original Articles}

119 The Burden of Mucosal Barrier Injury Laboratory-Confirmed Bloodstream Infection among Hematology, Oncology, and Stem Cell Transplant Patients Kristen E. Metzger, Yvonne Rucker, Mary Callaghan, Michelle Churchill, Borko D. Jovanovic, Teresa R. Zembower, and Maureen K. Bolon

125 A Comparison Between National Healthcare Safety Network Laboratory-Identified Event Reporting versus Traditional Surveillance for Clostridium difficile Infection

Michael J. Durkin, Arthur W. Baker, Kristen V. Dicks, Sarah S. Lewis, Luke F. Chen, Deverick J. Anderson, Daniel J. Sexton, and Rebekah W. Moehring

132 Comorbidities, Exposure to Medications, and the Risk of Community-Acquired Clostridium difficile Infection: A Systematic Review and Meta-analysis

Luis Furuya-Kanamori, Jennifer C. Stone, Justin Clark, Samantha J. McKenzie, Laith Yakob, David L. Paterson, Thomas V. Riley, Suhail A. R. Doi, and Archie C. Clements

142 Antimicrobial Stewardship in Outpatient Settings: A Systematic Review Dimitri M. Drekonja, Gregory A. Filice, Nancy Greer, Andrew Olson, Roderick MacDonald, Indulis Rutks, and Timothy J. Wilt

153 Antibiotics for Respiratory Tract Infections: A Comparison of Prescribing in an Outpatient Setting Tamar F. Barlam, Jake R. Morgan, Lee M. Wetzler, Cindy L. Christiansen, and Mari-Lynn Drainoni

160 Rapid, Highly Discriminatory Binary Genotyping to Demonstrate Methicillin-Resistant Staphylococcus aureus Transmission in a Tertiary Care Intensive Care Unit

C. W. Sadler, V. Nayyar, E. R. Stachowski, M. V. N. O'Sullivan, G. L. Gilbert, and K. Byth

169 Triclosan-Coated Sutures Reduce the Risk of Surgical Site Infections: A Systematic Review and Meta-analysis Anucha Apisarnthanarak, Nalini Singh, Aila Nica Bandong, and Gilbert Madriaga

180 Precautionary Practices of Healthcare Workers Who Disinfect Medical and Dental Devices Using High-Level Disinfectants

Scott A. Henn, James M. Boiano, and Andrea L. Steege

186 Vaccination Policies Among Health Professional Schools: Evidence of Immunity and Allowance of Vaccination Exemptions

Samantha B. Dolan, Tanya E. Libby, Megan C. Lindley, Faruque Ahmed, John Stevenson, and Raymond A. Strikas

192 Evaluation of a Pulsed Xenon Ultraviolet Disinfection System for Reduction of Healthcare-Associated Pathogens in Hospital Rooms Michelle M. Nerandzic, Priyaleela Thota, Thriveen Sankar C., Annette Jencson, Jennifer L. Cadnum, Amy J. Ray, Robert A. Salata, Richard R. Watkins, and Curtis J. Donskey

198 Pseudo-outbreak of Mycobacterium gordonae Following the Opening of a Newly Constructed Hospital at a Chicago Medical Center

Kavitha Prabaker, Chethra Muthiah, Mary K. Hayden, Robert A. Weinstein, Jyothirmai Cheerala, Mary L. Scorza, John Segreti, Mary A. Lavin, Barbara A. Schmitt, Sharon F. Welbel, Kathleen G. Beavis, and Gordon M. Trenholme 
204 Systematic Review With Meta-Analyses and Critical Appraisal of Clinical Prediction Rules for Pulmonary Tuberculosis in Hospitals

Berenice das Dores Gonçalves, Sonia Regina Lambert Passos, Maria Angelica Borges dos Santos, Carlos

Augusto Ferreira de Andrade, Maria de Fátima Moreira Martins, and Fernanda Carvalho de Queiroz Mello

\section{Concise Communications}

214 Risk Factors for Central Line-Associated Bloodstream Infections in the Era of Prevention Bundles Devin Callister, Pauline Limchaiyawat, Samantha J. Eells, and Loren G. Miller

217 Gut Check: Clostridium difficile Testing and Treatment in the Molecular Testing Era

Whitney R. Buckel, Edina Avdic, Karen C. Carroll, Vidhya Gunaseelan, Eric Hadhazy, and Sara E. Cosgrove

222 Outpatient Parenteral Antimicrobial Therapy in Pediatrics: An Opportunity to Expand Antimicrobial Stewardship Elizabeth D. Knackstedt, Chris Stockmann, Carly R. Davis, Emily A. Thorell, Andrew T. Pavia, and Adam L. Hersh

225 Surgical Site Infection Surveillance Following Ambulatory Surgery Chanu Rhee, Susan S. Huang, Sandra I. Berrios-Torres, Rebecca Kaganov, Christina Bruce, Julie Lankiewicz, Richard Platt, Deborah S. Yokoe, and for the Centers for Disease Control and Prevention (CDC) Prevention Epicenters Program

229 Efficacy of Alcohol Gel for Removal of Methicillin-Resistant Staphylococcus Aureus from Hands of Colonized Patients Venkata Sunkesula, Sirisha Kundrapu, David R. Macinga, and Curtis J. Donskey

\section{Research Brief}

232 Low Prevalence of Mupirocin Resistance Among Hospital-Acquired Methicillin-Resistant Staphylococcus aureus Isolates in a Neonatal Intensive Care Unit with an Active Surveillance Cultures and Decolonization Program

Nuntra Suwantarat, Karen C. Carroll, Tsigereda Tekle, Tracy Ross, Victor O. Popoola, and Aaron M. Milstone

\section{Letters to the Editor}

235 Surveillance of Methicillin-Resistant Staphylococcus aureus Mupirocin Resistance in a Veterans Affairs Hospital Carmen V. Sciortino, Mary Kemper, Latha Parthasarathy, and James Lay

236 Sampling Plans for Use of Rapid Adenosine Triphosphate (ATP) Monitoring Must Overcome Variability or Suffer Statistical Invalidity

Greg S. Whiteley, Chris Derry, and Trevor Glasbey

237 Reply to Whiteley et al

Kavel H. Visrodia, Cori L. Ofstead, Harry P. Wetzler, Pritish K. Tosh, and Todd H. Baron

239 Infection Control and Prevention Programs in Integrated Healthcare Delivery Systems in the Time of Ebola and Enterovirus D68: The Challenge Before Us

Leonard A. Mermel 
An Official Publication of the Society for Healthcare Epidemiology of America

\section{EDITOR}

Suzanne F. Bradley, MD • Ann Arbor, MI

\section{DEPUTY EDITOR}

Carol A. Kauffman, MD • Ann Arbor, MI

\section{SENIOR ASSOCIATE EDITORS}

C. Glen Mayhall, MD • Galveston, TX

Gina Pugliese, RN, MS • Chicago, IL

William Schaffner, MD • Nashville, TN

\section{ASSOCIATE EDITORS}

Carol Chenoweth, MD • Ann Arbor, MI

Ebbing Lautenbach, MD, MPH • Philadelphia, PA

David Weber, MD, MPH • Chapel Hill, NC

\section{STATISTICS CONSULTANTS}

Jon P. Furuno, PhD • Portland, OR

Jessina C. McGregor, PhD • Portland, OR

SECTION EDITOR FOR GUIDELINES, POSITION PAPERS, AND INVITED REVIEWS

Eli Perencevich, MD, MS • Iowa City, IA

MANAGING EDITOR

Meighan Schreiber, MSSA • New York, NY

\section{PAST EDITORS}

Infection Control

Richard P. Wenzel, MD, 1980-1987 (vols. 1-8)

Infection Control \& Hospital Epidemiology

Richard P. Wenzel, MD, 1988-1992

(vols. 9-13)

Michael D. Decker, MD, 1993-2001 (vols. 14-22)

Barry M. Farr, MD, 2002-2004 (vols. 23-25)

William R. Jarvis, MD, 2005-2006 (vols. 26 and 27)

\author{
EDITORIAL ADVISORY BOARD \\ Deverick Anderson, MD, MPH • Durham, NC \\ Anucha Apisarnthanarak, MD • Pratumthani, Thailand \\ Lennox Archibald, MD, FRCP • Alachua, FL \\ Hilary Babcock, MD • St. Louis, MO \\ Shailen Banerjee, PhD • Atlanta, GA \\ Elise M. Beltrami, MD, MPH • Atlanta, GA \\ Jo Anne Bennett, RN, PhD • New York, NY \\ David Birnbaum, PhD, MPH • Sidney, BC \\ Marc Bonten, MD • Utrecht, Netherlands \\ Christian Brun-Buisson, MD • Creteil, France \\ John P. Burke, MD • Salt Lake City, UT \\ David P. Calfee, MD, MS • New York, NY \\ Yehuda Carmeli, MD, MPH • Tel Aviv, Israel \\ Donald E. Craven, MD • Burlington, MA \\ Christopher Crnich, MD, MS • Madison, WI \\ Erika D’Agata, MD, MPH • Boston, MA \\ Daniel Diekema, MD • Iowa City, IA \\ Erik Dubberke, MD, MSPH • St. Louis, MO \\ Charles E. Edmiston, Jr., PhD • Milwaukee, WI \\ Theodore C. Eickhoff, MD • Denver, CO \\ Mohamad Fakih, MD, MPH • Grosse Pointe Woods, MI \\ Petra Gastmeier, MD • Berlin, Germany \\ Jeffrey Gerber, MD, PhD • Philadelphia, PA \\ Dale N. Gerding, MD • Hines, IL \\ Donald A. Goldmann, MD • Boston, MA \\ Nicholas Graves, PhD • Brisbane, Australia \\ Donna Haiduven, RN, PhD, CIC • Tampa, FL \\ Anthony D. Harris, MD, MPH • Baltimore, MD \\ Elizabeth Henderson, PhD • Calgary, AB \\ David K. Henderson, MD • Bethesda, MD \\ Loreen A. Herwaldt, MD • Iowa City, IA
}

Peter N. R. Heseltine, MD • Brea, CA

John A. Jernigan, MD, MS • Atlanta, GA

James T. Lee, MD, PhD • St. Paul, MN

L. Clifford McDonald, MD • Atlanta, GA

Allison McGeer, MD • Toronto, ON

Leonard A. Mermel, DO, ScM • Providence, RI

Robert R. Muder, MD • Pittsburgh, PA

Linda Mundy, MD • Collegeville, PA

Joseph M. Mylotte, MD, CIC • Buffalo, NY

Jan Evans Patterson, MD • San Antonio, TX

David A. Pegues, MD • Philadelphia, PA

Didier Pittet, MD, MS • Geneva, Switzerland

Isaam Raad, MD • Houston, TX

Manfred L. Rotter, MD, DipBact • Vienna, Austria

William A. Rutala, PhD, MPH • Chapel Hill, NC

Lisa Saiman, MD, MPH • New York, NY

Sanjay Saint, MD, MPH • Ann Arbor, MI

Sorana Segal-Maurer, MD • Flushing, NY

Lynne M. Sehulster, PhD • Atlanta, GA

John A. Sellick, DO • Amherst, NY

Kent Sepkowitz, MD • New York, NY

Andrew E. Simor, MD • Toronto, ON

Philip W. Smith, MD • Omaha, NE

Kurt Stevenson, MD, MPH • Columbus, $\mathrm{OH}$

Nimalie Stone, MD • Atlanta, GA

Thomas Talbot, MD, MPH • Nashville, TN

Paul Tambyah, MBBS • Singapore

William Trick, MD • Chicago, IL

Antoni Trilla, MD, PhD • Barcelona, Spain

Robert A. Weinstein, MD • Chicago, IL

Andreas Widmer, MD, MS • Basel, Switzerland

Marcus Zervos, MD • Detroit, MI
Infection Control \& Hospital Epidemiology (ISSN 0899-823X) is published monthly by Cambridge University Press, 32 Avenue of the Americas, New York, NY 10013, USA.

\section{Editorial Office}

Communications should be addressed to the Editor, Infection Control \& Hospital Epidemiology, 32 Avenue of the Americas, New York, NY 10013 (email: mschreiber@cambridge.org; telephone: 212-337-5954, fax: 212337-5959). Contributors should consult the Instructions for Contributors, which is available at the journal's Web site.

\section{Advertising}

Please direct advertising inquiries to M. J. Mrvica Associates, 2 West Taunton Avenue, Berlin, NJ 08009 (e-mail: mjmrvica@mrvica.com; telephone: 856-768-9360, fax: 856-753-0064). Publication of an advertisement in Infection Control \& Hospital Epidemiology does not imply endorsement of its claims by the Society for Healthcare Epidemiology of America, by the Editor, or by Cambridge University Press.

\section{Permissions}

Articles may be copied or otherwise reused without permission only to the extent permitted by Sections 107 and 108 of the US Copyright Law. Permission to copy articles for personal, internal, classroom, or library use may be obtained from the Copyright Clearance Center (http://www. copyright.com, email: info@copyright.com). For all other uses, such as copying for general distribution, for advertising or promotional purposes, for creating new collective works, or for resale, please contact Cambridge University Press. Full details may be found at: www.cambridge.org/aboutus/rights-permissions.

\section{Subscriptions}

The individual subscription rate for 2015 is \$224. Individuals have the option to order directly from Cambridge University Press. Institutional print + electronic and e-only subscriptions are available from Cambridge University Press and include unlimited online access; rates are tiered according to an institution's type and research output and may be reviewed at the journal's CJO homepage: http://journals.cambridge.org/ICE.

Please direct subscription inquiries and requests for back issues to Customer Services at Cambridge University Press, e-mail: subscriptions_newyork@ cambridge.org (USA, Canada, and Mexico) or journals@cambridge.org (outside of USA, Canada, and Mexico).

Postmaster: Send address changes to Infection Control \& Hospital Epidemiology, Cambridge University Press, 100 Brook Hill Drive, West Nyack, NY 10994-2133, USA. 
About the cover:

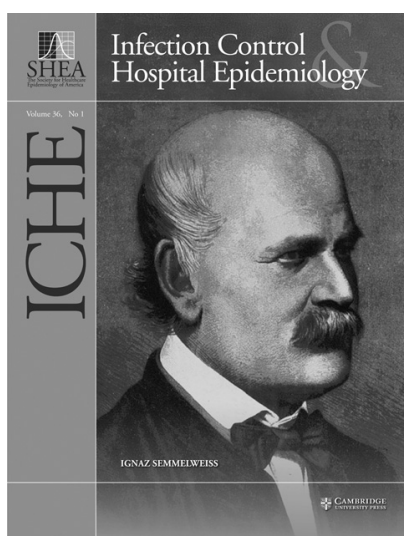

Starting in 2015, the cover format of each volume of Infection Control \& Hospital Epidemiology will highlight one of the many professionals throughout history who not only recognized how disease might be spread, but also how epidemiological principles could be applied to reduce healthcare associated infections.

Ignaz Semmelweiss (1818-1865) was a Hungarian physician who was appointed an assistant in obstetrics at the Allgemeine Krakenhaus in Vienna. He recognized that women delivered by midwife trainees were significantly less likely to die of puerperal fever than those delivered by physicians or medical students. He hypothesized that puerperal fever could be spread to mothers at the time of delivery by the hands of obstetricians that became contaminated while performing autopsies on women who had died in the maternity ward. Controlled trials of hand washing with chloride of lime solution and disinfection of instruments showed that he could reduce infections among the women cared for by physicians by almost 20 -fold. Unfortunately, he did not publish his findings which contributed to the lack of acceptance of antisepsis among senior staff; Semmelweiss' academic appointment was not renewed. He left for Budapest, but his beliefs failed to gain traction among colleagues in Hungary. Semmelweiss' increasingly erratic and angry behavior led to commitment to an asylum; he died there within a few short weeks at the age of 47 years. Contrary to legend, Semmelweiss' autopsy suggests that he did not die of streptococcal gangrene, but rather of trauma related to beatings inflicted by the guards at the asylum and an early Alzheimer-type dementia. 